\title{
Core Values of Graduate Students in the Context of Lesson Study Process
}

\author{
Alisa Moonsri ${ }^{1,2}$, Maitree Inprasitha ${ }^{1,2} \&$ Narumon Changsri ${ }^{1,2}$ \\ ${ }^{1}$ Mathematics Education Program, Faculty of Education, Khon Kaen University, Thailand \\ ${ }^{2}$ Center of Excellence in Mathematics, CHE, Si Ayutthaya RD., Bangkok, Thailand \\ Correspondence: Maitree Inprasitha, Mathematics Education Program, Faculty of Education, Khon Kaen 40002 , \\ Thailand. E-mail: inprasitha_crme@kku.ac.th
}

Received: May 5, 2021; Accepted: June 16, 2021; Published: June 19, 2021

\begin{abstract}
The purpose of this research was planned to explore graduate students' core values in the context of the Lesson Study process. The selected research institute is a Faculty of Education of a public university in Khon Kaen province, Thailand. A total of 59 samples were purposively selected to participate in a survey. The target group was selected based on the condition that they are studying Mathematics Education Graduate Program for not less than one year and have practiced several cycles of the Lesson Study process during their studies. The target group consisted of 40 and 19 samples who are currently doing their master's and doctoral studies, respectively. This research utilized the Thailand Lesson Study Model (Inprasitha, 2010) consisting of three steps, namely (i) collaboratively design a research lesson (Plan); (ii) collaboratively observe the research lesson (Do), and (iii) collaboratively discuss and reflect on the research lesson (See) in terms of the four core values, namely building collaboration, open-minded attitudes, public concern, and emphasis on product-process approach (Inprasitha, 2015). Data were collected using a questionnaire and reflection online blog. The survey results revealed that there are different levels of practicing the four core values at each step of the Lesson Study process in different training activities. In conclusion, the results of this research have successfully contributed to our recognition of the importance of core values while graduate students in the context of the Lesson Study process.
\end{abstract}

Keywords: core values, graduate students, Lesson Study, preparing context

\section{Introduction}

Teachers play a vital role to educate and shape students' lives, therefore teaching is one of the most significant careers in our society. As such, teaching is not only enduring a very thought-provoking duty but also teachers have to commit themselves to teach by holding specific values that inspire and stimulate them to devote their lives to others (Elik, Wiener, \& Corkum, 2020). Inprasitha (2015) disagreed with the conventional method used by mathematics teachers in Thailand while they were teaching mathematics. In general, mathematics teachers were preparing lesson plans by themselves, teaching those lesson plans in their closed classroom, checking the assigned homework, making some quizzes, and prescribing exercise as part and parcel of their routine work (Inprasitha, 2015). This conventional teaching practice in Thailand was also indicated by Kaewdang (2000) and Khammani (2012). For instance, a mathematics teacher begins by explaining new content, giving some examples, then giving students some exercises, and allocating some homework, or representing, enquiring, describing, and lecturing.

Certainly, this conventional teaching practice as mentioned above failed to respond to the new demand of knowledge and skills as the core values for the $21^{\text {st }}$ century that we are currently struggling with (Levy \& Murnane, 2004). According to Hill, Rowan, and Ball (2005), teachers' mathematical knowledge, skills, values, and habits of mind would contribute to developing teachers' mathematical knowledge for teaching. Moreover, the effect of teachers' mathematical knowledge of teaching on students' mathematics is undeniable great (Hill et al., 2005). Besides, mathematics teachers also need to possess skills in anticipating and interpreting students' ideas and ways of thinking about mathematics. Therefore, professional teaching development is grounded in explicit attention to student thinking and has been proved by past researchers on the positive impacts to student mathematics learning (Fennema et al., 1996).

Lesson Study is an innovative method for enlightening student learning and teachers' professional development incorporates observations made by teachers which are later analyzed. Lesson study was originated in Japan in the late $19^{\text {th }}$ century and has been recognized as a teaching improvement process around the globe (Shimizu \& Chino, 
2015). Takahashi (2006) explained the original ideas of Lesson Study in Japan as teachers work collaboratively with one another in a small group, meet together to discuss lesson plans or research lessons, then observe how their ideas work in an actual lesson with students, and finally report on the observation results so that the small group of teachers can benefit from it.

Before entering the $21^{\text {st }}$ century, many attempts have been tried to shift the teaching paradigm, particularly the method to teach mathematics from prominence on teacher-centered to student-centered approach (Calkins \& Light, 2008). Moreover, a study published by the National Staff Development Council (NSDC) has affirmed the high standard of the Singapore education system and recognized the effective strategies put in place by the Singapore Ministry of Education concerning teachers' professional development through Lesson Study (Wei, DarlingHammond, Andree, Richardson, \& Orphanos, 2009). Thailand like many countries is facing the challenge of preparing students for life and work in the $21^{\text {st }}$ century (Inprasitha, 2015). As a result, the original ideas of Lesson Study would be benefited teachers to change their instructional approaches in the classroom to develop their teaching competencies and achieve the desired outcomes of human capital in the $21^{\text {st }}$ century (Yeap, Foo, \& Soh, 2015).

The development of the mathematics teaching approach has channeled on reconciling among these issues, namely the new aspects of mathematics (Becker \& Shimada, 1997), students' differences (Graff \& Byrne, 2002), and problem-solving as a teaching approach (Nohda, 1991). For example, an emphasis on mathematical thinking in the mathematics teaching approach is an endeavor in Japan (Becker \& Shimada, 1997) as elucidated in the learning courses of mathematics education programs. Furthermore, the innovative teaching approach is quite challenging because the focus of students' mathematical thinking has to take into account individual differences in terms of the suitability of mathematical contents. This was mentioned by Isoda and Nakamura (2010) as the new teaching approach was found to be problematic to implement in classrooms around the globe, for instance, changing the focus on the correct answers or closed mathematical problems to assess students' mathematical higher-order thinking (Shimizu, 1999). The major concern is tackling students' problem-solving skills in corresponding to their differences, particularly students' different ways of thinking abilities (Takahashi, 2006).

The above development of the mathematics teaching approach in Japan has triggered Inprasitha (2003) to propose a paradigm change in the Thailand context by incorporating an Open Approach in the Lesson Study process. The Open Approach refers to using an open-ended problem at the beginning of the lesson to focus on students' thinking process for the given tasks. The key concern is every student has his or her problem that he or she has to solve the problem independently or the teacher encourages students to think by themselves (Brown \& Walter, 2005). Inprasitha (2010) created a modified Thailand Lesson Study Model by incorporated Open Approach in the second step of the Lesson Study process as illustrated in Figure 1.

The Lesson Study process under Thailand context consists of three steps, namely (i) collaboratively design a research lesson (Plan); (ii) collaboratively observe the research lesson (Do), and (iii) collaboratively discuss and reflect on the research lesson (Inprasitha, 2009). On the other hand, the Open Approach that incorporated in the second step of the Lesson Study process is comprised of four phases, namely (i) posing open-ended problems; (ii) students' self-learning; (iii) whole-class discussion and comparison, and (iv) summarize by connecting students' mathematical ideas emerged in the classroom.

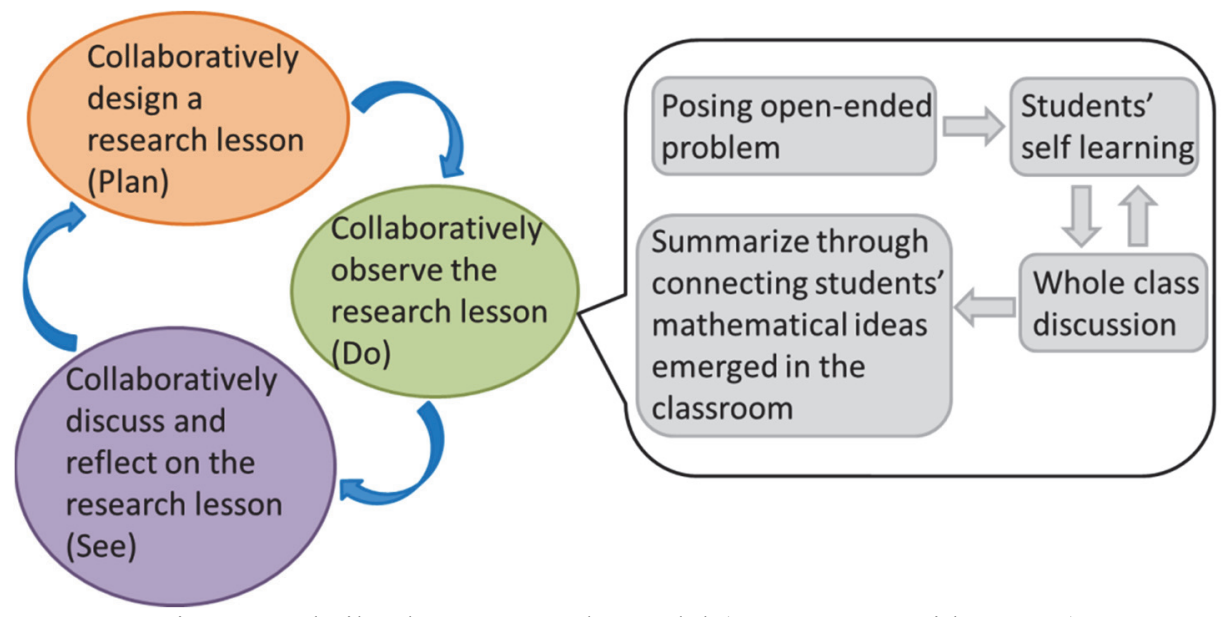

Figure 1. Thailand Lesson Study Model (Source: Inprasitha, 2010) 
The above model is designed to motivate mathematics teachers to teach using teaching and learning activities based on open-ended problems with the intention to be institutionalized into Thailand's school culture. According to Inprasitha (2010), the teachers' core value differences can cause the innovative teaching approaches very hard to accept and apply in their teaching. On the other hand, the existing Teacher Preparation Program in Mathematics Education and its graduate-level was revised by emphasizing higher-order thinking rather than rote learning of mathematical rules or formulas.

The impact of mathematics teachers' core values and the way these core values are expressed in classroom teaching has been consistently debated in education. In this line of reasoning, the teaching task is certainly problematic because it implies the establishment of a mathematics teacher's personal as well as professional development and involves a consideration of the core values that inform the mathematics teacher's teaching practice (Brady, 2011). Consequently, researchers conceptualized four core values of the perspective of values education, namely (i) building collaboration; (ii) open-minded attitudes; (iii) public concern, and (iv) emphasis on product-process approach by referring to Inprasitha's (2015) Core Values Framework for Teacher Preparation Program in Mathematics Education. Figure 2 illustrates the training activities in Teacher Preparation of Mathematics Education.

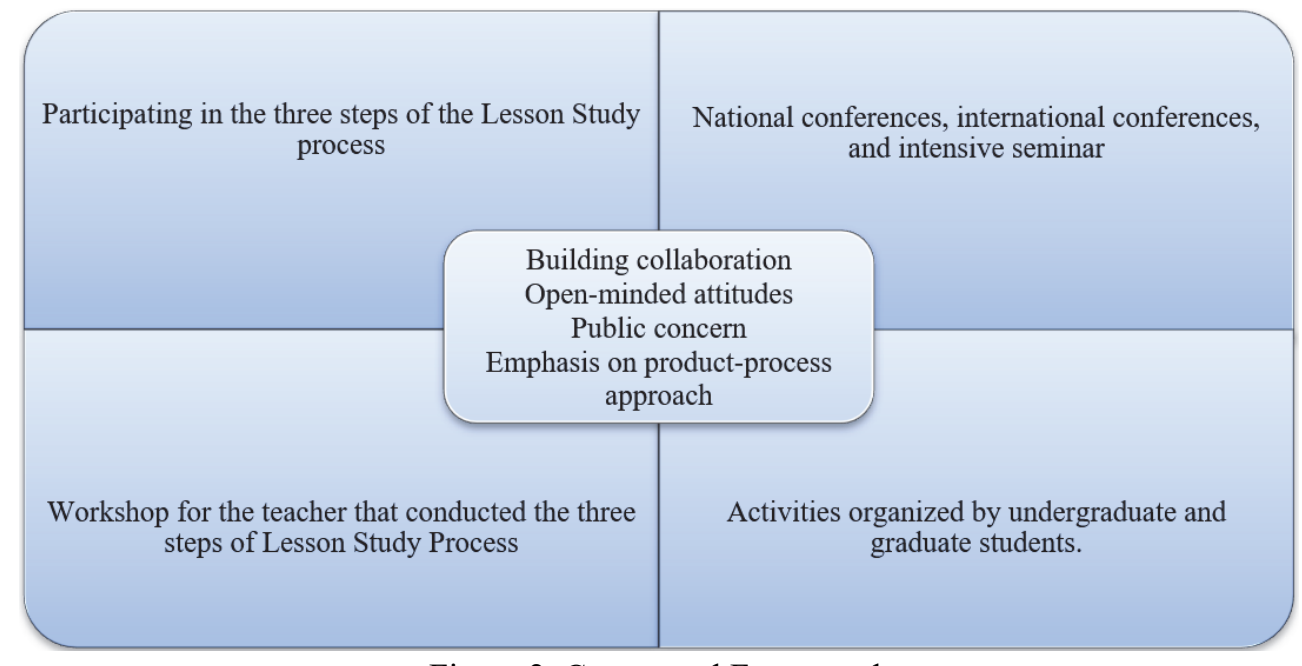

Figure 2. Conceptual Framework

Based on the conceptual framework, the researchers aimed to explore the core values namely (i) building collaboration; (ii) open-minded attitudes; (iii) public concern, and (iv) emphasis on product-process approach that occurred when graduate students in preparing context along with Lesson Study training activities in a public university, Thailand. The training activities include: (i) Participating in the-three steps of the Lesson Study process; (ii) National conferences, international conferences, and intensive seminar that conducted in the-three steps of lesson study; (iii) Workshop for the teacher that conducted in the-three steps of Lesson Study, and (iv) Activities organized by undergraduate and graduate students.

\section{Method}

The researchers employed a survey design using a questionnaire and reflection form to elicit information about core values when samples were preparing context using the Thailand Lesson Study Model (Refer Figure 1). A quantitative approach using a questionnaire and a qualitative approach using group reflection online are suitable to apply because the researchers aimed to convey meaning and comprehension via detailed description. It is considered as a powerful method to explore core values practice through the training activities of the Teacher Preparation Graduate Program in Mathematics Education that samples attended throughout their studies.

A total of 59 Mathematics Education program students were purposively selected to participate in the survey. The target group was selected based on the condition that they have practiced the Lesson Study process through training activities during their studies in Graduate Program (Mathematics Education). The target group consisted of 40 and 19 samples who are currently doing their master's and doctoral studies in Teacher Preparation Graduate Program in Mathematics Education, respectively. The researchers used a questionnaire and the online reflection blogs to record the possible core values practice through the four aspects of training activities. The obtained data were analyzed using descriptive statistics and content analysis as well. 


\section{Results}

The results of this research are presented in parallel with the research aims and conceptual framework with the four training activities. Moreover, the quantitative results from the questionnaires were triangulated with the qualitative data from the online reflective blogs.

\subsection{Core Values Practice while Participating in the Three Steps of the Lesson Study Process}

The results revealed that graduate students practiced all four core values when they participated in the three steps of the Lesson Study process, namely collaborative plan, do, and see. Specifically considering in descending order, found that the most practicing core values are values of emphasis on the product-process approach, building collaboration, open-minded attitudes, and public concern. Table 1 shows the quantitative results of core values while samples were participating in the three steps of the Lesson Study process.

Table 1. Core values practice while participating in the-three steps of the Lesson Study process

\begin{tabular}{lllll}
\hline Core values & $\begin{array}{l}\text { Building } \\
\text { collaboration } \\
(\%)\end{array}$ & $\begin{array}{l}\text { Open-minded } \\
\text { attitudes } \\
(\%)\end{array}$ & $\begin{array}{l}\text { Public } \\
\text { concern } \\
(\%)\end{array}$ & $\begin{array}{l}\text { Emphasis on } \\
\text { product-process } \\
(\%)\end{array}$ \\
\hline Step 1 (Plan) & & & & \\
\hline Design problem situations. & 81.25 & 53.13 & 31.25 & 93.75 \\
Create instructions using keywords. & 78.13 & 65.63 & 21.88 & 90.63 \\
Anticipate students' ideas. & 75.00 & 59.38 & 21.88 & 90.63 \\
Design core and supplementary media. & 81.25 & 56.25 & 21.88 & 84.38 \\
Learning focus on the real-world. & 75.00 & 40.63 & 25.00 & 87.50 \\
\hline Step 2 (Do) & & & & \\
\hline Manage learning activities. & 81.25 & 31.25 & 25.00 & 87.50 \\
Do not modify plans. & 68.75 & 31.25 & 18.75 & 93.75 \\
Present relevant problem situation. & 62.50 & 40.63 & 15.63 & 87.50 \\
Do not provide additional terms. & 56.25 & 31.25 & 15.63 & 90.63 \\
Observe students' concepts. & 68.75 & 43.75 & 15.63 & 90.63 \\
Observe different concepts. & 68.75 & 43.75 & 15.63 & 90.63 \\
Record students' ideas. & 59.38 & 46.88 & 21.88 & 90.63 \\
Rank ideas to organize a presentation. & 65.63 & 46.88 & 12.50 & 93.75 \\
Students introduce their ideas. & 59.38 & 71.88 & 34.38 & 90.63 \\
Not judging students' ideas. & 53.13 & 78.13 & 37.50 & 84.38 \\
Summarize what students learned. & 59.38 & 62.50 & 31.25 & 93.75 \\
Do not summarize teachers' plans. & 59.38 & 50.00 & 21.88 & 87.50 \\
\hline Step 3 (See) & & & \\
\hline Reflect expected ideas. & 78.13 & 50.00 & 25.00 & 90.63 \\
Check the consistency to the real world. & 75.00 & 56.25 & 25.00 & 84.38 \\
Relevancy keywords to command. & 75.00 & 46.88 & 21.88 & 87.50 \\
\hline
\end{tabular}

\subsection{Core Values Practice while Participating in National Conferences, International Conferences, and Intensive Seminars That Conducted The-Three Steps of Lesson Study Process}

The results indicated that graduate students are practicing values of emphasis on product-process approach, building collaboration, and open-minded attitudes, in that order while they are collaboratively designing a research lesson at national conferences, international conferences, and intensive seminars. They continued practicing the values of emphasis on the product-process approach and building collaboration, added the value of public concern at the second step while they are collaboratively observing the research lessons. However, the value of building collaboration is more frequently practiced than the emphasis on the product-process approach in the second and third steps. The other two core values, namely public concern and open-minded attitudes are core values that have less capacity while they are participating in national conferences, international conferences, and intensive seminars that conducted the-three steps of Lesson Study. Table 2 illustrates the quantitative results of core values while samples were participating in national conferences, international conferences, and intensive seminars that conducted the-three steps of the Lesson Study process. 
Table 2. Core values practice while participating in conferences or seminars that conducted the-three steps of the Lesson Study process

\begin{tabular}{lllll}
\hline Core values & $\begin{array}{l}\text { Building } \\
\text { collaboration } \\
(\%)\end{array}$ & $\begin{array}{l}\text { Open-minded } \\
\text { attitudes } \\
(\%)\end{array}$ & $\begin{array}{l}\text { Public concern } \\
(\%)\end{array}$ & $\begin{array}{l}\text { Emphasis on } \\
\text { product-process } \\
(\%)\end{array}$ \\
\hline Step 1 (Plan) & & & & \\
\hline Preparing abstract and manuscript. & 78.13 & 59.38 & 37.50 & 81.25 \\
Discuss issues for preparation. & 87.50 & 53.13 & 40.63 & 78.13 \\
Arrangement for attendance. & 84.38 & 68.75 & 59.38 & 75.00 \\
Report the performance. & 81.25 & 71.88 & 65.63 & 78.13 \\
\hline Step 2 (Do) & & & \\
\hline Write abstract and manuscript. & 68.75 & 34.38 & 37.50 & 87.50 \\
Rehearsal presentation. & 78.13 & 59.38 & 53.13 & 78.13 \\
Attend seminar/conference. & 81.25 & 53.13 & 56.25 & 87.50 \\
Operate as what has been planned. & 84.38 & 62.50 & 65.63 & 87.50 \\
\hline Step 3 (See) & & & & \\
\hline Daily reflection meeting. & 87.50 & 71.88 & 56.25 & 93.75 \\
Problem identification. & 87.50 & 81.25 & 65.63 & 93.75 \\
Reflect on overall performance. & 84.38 & 78.13 & 68.75 & 96.88 \\
\hline
\end{tabular}

\subsection{Core Values Practice while Participating Workshop for Teacher that Conducted the-Three Steps of Lesson Study Process}

The results showed that graduate students practiced all four core values when they participated in the workshop for the teacher that conducted the-three steps of the Lesson Study process. Precisely considering in descending order, found that the most to the least practicing core values are values of emphasis on product-process approach, building collaboration, open-minded attitudes, and public concern. Table 3 elucidates the quantitative results of core values while samples were participating in the workshop for teachers that conducted the-three steps of the Lesson Study process.

Table 3. Core values practice while participating in the workshop for teachers that conducted the-three steps of the Lesson Study process

\begin{tabular}{lllll}
\hline Core values & $\begin{array}{l}\text { Building } \\
\text { collabora- } \\
\text { tion } \\
(\%)\end{array}$ & $\begin{array}{l}\text { Open- } \\
\text { minded } \\
\text { attitudes } \\
(\%)\end{array}$ & $\begin{array}{l}\text { Public } \\
\text { concern } \\
(\%)\end{array}$ & $\begin{array}{l}\text { Emphasis on } \\
\text { product- } \\
\text { process } \\
(\%)\end{array}$ \\
\hline Step 1 (Plan) & & & & \\
\hline Understand guidelines of operation. & 87.50 & 68.75 & 50.00 & 87.50 \\
Operational planning meeting. & 90.63 & 71.88 & 59.38 & 87.50 \\
Report the performance. & 81.25 & 68.75 & 59.38 & 90.63 \\
\hline Step 2 (Do) & & & & \\
\hline Implement the work plan. & 87.50 & 62.50 & 62.50 & 81.25 \\
Observe and record operation problems. & 81.25 & 71.88 & 75.00 & 78.13 \\
\hline Step 3 (See) & & & & \\
\hline Report daily operation. & 84.38 & 78.13 & 62.50 & 87.50 \\
Reflect overall performance. & 84.38 & 78.13 & 62.50 & 81.25 \\
\hline
\end{tabular}

\subsection{Core Values Practice while Participating Activities Organized by Undergraduate and Graduate Students}

Those activities that were organized by the undergraduate and graduate students such as the Undergraduate Seminar by senior students, the Mathematics Camp, the Anniversary of the Center for Research in Mathematics Education that conducted the-three steps of the Lesson Study process. The results revealed that core values practice in descending order as follows: building collaboration, emphasis on product-process approach, open-minded attitudes, and public concern. Table 4 demonstrates the quantitative results of core values practice while samples were participating in activities organized by undergraduate and graduate students. 
Table 4. Core values practice while participating in activities organized by undergraduate and graduate students

\begin{tabular}{|c|c|c|c|c|}
\hline Core values & $\begin{array}{c}\text { Building } \\
\text { collabora- } \\
\text { tion } \\
(\%)\end{array}$ & $\begin{array}{c}\text { Open- } \\
\text { minded } \\
\text { attitudes } \\
(\%)\end{array}$ & $\begin{array}{c}\text { Public } \\
\text { concern } \\
(\%)\end{array}$ & $\begin{array}{c}\text { Emphasis on } \\
\text { product- } \\
\text { process } \\
(\%)\end{array}$ \\
\hline \multicolumn{5}{|l|}{ Step 1 (Plan) } \\
\hline Understand how to organize activities. & 84.38 & 78.13 & 65.63 & 84.38 \\
\hline Operational planning meeting. & 87.50 & 75.00 & 68.75 & 78.13 \\
\hline Report the performance. & 87.50 & 75.00 & 59.38 & 84.38 \\
\hline \multicolumn{5}{|l|}{ Step 2 (Do) } \\
\hline Implement the work plan. & 81.25 & 53.13 & 53.13 & 81.25 \\
\hline Observe and record operation problems. & 81.25 & 65.63 & 68.75 & 87.50 \\
\hline \multicolumn{5}{|l|}{ Step 3 (See) } \\
\hline Report daily operation. & 84.38 & 78.13 & 65.63 & 81.25 \\
\hline Reflect overall performance. & 84.38 & 75.00 & 65.63 & 84.38 \\
\hline
\end{tabular}

\section{Discussion and Conclusion}

The overview of results implies that a core values-driven of the teacher education program are important to take into consideration these four core values, particularly values of emphasis on product-process approach and building collaboration. Nevertheless, the other core values such as open-minded attitudes and public concern cannot be neglected too. On the other hand, three major core concepts are found essential in enhancing the Lesson Study process, namely problem-solving skills as a driving force in promoting mathematical thinking, teacher learning collaboratively, and teachers' reflections for future improvement. The Thailand Lesson Study Model (Inprasitha, 2010) should be practically utilized nationwide because the Open Approach is a teaching method and Lesson Study is a method to improve teaching.

Moreover, post-graduate students would play an active mediating in the-three steps of the Lesson Study process, including collaboratively design a research lesson, observe the research lesson, and discuss and reflect on the research lesson. Besides, all four core values can increase the graduate students' psychological preparation level if the planned strategies of the Lesson Study process can lead to a better and positive learning culture, as emphasized by Elik et al. (2020). Future research should be devoted to the evaluation of strategies to determine whether the core values still have room for improvement in producing attitude change (Brady, 2011).

In conclusion, the researchers would like to suggest to the Thailand Ministry of Education to promote Lesson Study incorporated Open Approach model so that teaching and learning arrangement is based upon the studentcentered approach in corresponding to active learning. It is, therefore, the mathematics learning strategies should enable students to engage themselves in the learning process, develop their learning to match their potential, interest, and aptitude (Phala \& Chamrat, 2019). The graduate students are encouraged to think actively and independently to construct the knowledge through the Lesson Study process for their meaningful learning.

\section{Acknowledgments}

This research work was supported by the Centre of Excellence in Mathematics, The Commission on Higher Education, Thailand and the Centre for Research in Mathematics Education (CRME), Khon Kaen University, Khon Kaen 40002, Thailand. The contents of this manuscript are derived from the first author's doctoral dissertation thus fulfilling the Ph.D. requirement of Khon Kaen University.

\section{References}

Becker, J. P., \& Shimada, S. (1997). The open-ended approach: A new proposal for teaching mathematics. Reston, VA: National Council of Teachers of Mathematics.

Brady, L. (2011). Teacher values and relationship: Factors in values education. Australian Journal of Teacher Education, 36(2). https://doi.org/10.14221/ajte.2011v36n2.5

Brown, S. I., \& Walter, I. (2005). The art of problem posing (3rd ed.). Mahwah, NJ: Lawrence Erlbaum Associates. 
https://doi.org/10.4324/9781410611833

Calkins, S., \& Light, G. (2008). University teaching. In T. L. Good (Ed.), $21^{\text {st }}$ century education: A reference handbook, Volume 11 (pp. 445-454). London, UK: SAGE. https://doi.org/10.4135/9781412964012.n97

Elik, N., Wiener, J., \& Corkum, P. (2020). Pre-service teachers' open-minded thinking dispositions, readiness to learn, and attitudes about learning and behavioral difficulties in students. European Journal of Teacher Education, 33(2), 127-146. https://doi.org/10.1080/02619760903524658

Fennema, E., Carpenter, T. P., Franke, M. L., Levi, L., Jacob, V. R., \& Empson, S. B. (1996). A longitudinal study of learning to use children's thinking in mathematics instruction. Journal for Research in Mathematics Education, 27(4), 403-434. https://doi.org/10.2307/749875

Graff, M. G., \& Byrne, D. R. (2002). The effectiveness of e-learning: Cognitive style, navigation and disorientation in hypertext. E-Business Review, 2, 91-94.

Hill, H. C., Rowan, B., \& Ball, D. L. (2005). Effects of teachers' mathematical knowledge for teaching on student achievement. American Educational Research Journal, 42(2), 371-406. https://doi.org/10.3102/00028312042002371

Inprasitha, M. (2009). Lesson study: Innovation for developing teacher and students. Doctor of Education thesis. Khon Kaen, Thailand: Khon Kaen University.

Inprasitha, M. (2010). One feature of adaptive lesson study in Thailand: Designing a learning unit. Journal of Science and Mathematics Education in Southeast Asia, 34(1), 47-66.

Inprasitha, M. (2015). New model of teacher education program in mathematics education: Thailand experience. Paper presented at the ICMI-East Asia Regional Conference on Mathematics Education, Cebu City, the Philippines, May 11-15.

Isoda, M., \& Nakamura, T. (2010). Mathematics education theories for Lesson Study: Problem-solving approach and the curriculum through extension and integration. Journal of Japan Society of Mathematics Education, $92,5$.

Kaewdang, R. (2000). Indigenous knowledge for a learning society. Paper presented at the $6^{\text {th }}$ UNESCO-APEID International Conference on Education, Bangkok, Thailand, December 12-15.

Khammani, T. (2012). Science of teaching: Knowledge to the effective learning process. Bangkok, Thailand: Chulalongkorn University Printing House.

Levy, F., \& Murnane, R. J. (2004). The new division of labor: How computers are creating the next job market. Princeton, NJ: Princeton University Press. https://doi.org/10.1515/9781400845927

Nohda, N. (1991). Paradigm of the 'open-approach' method in mathematics teaching: Focus on mathematics problem-solving. Zentralblatt fur Didaktik der Mathematics, 23(2), 32-37.

Phala, J., \& Chamrat, S. (2019). Learner characteristics as consequences of active learning. Journal of Physic: Conference Series, 1340. https://doi.org/10.1088/1742-6596/1340/1/012083

Shimizu, Y. (1999). Aspects of mathematics teacher education in Japan: Focusing on teachers' roles. Journal of Mathematics Teacher Education, 2(1), 107-116. https://doi.org/10.1023/A:1009960710624

Shimizu, S., \& Chino, K. (2015). History of Lesson Study to develop good practices in Japan. In M. Inprasitha, M. Isoda, P. Wang-Iverson, \& B. H. Yeap (Eds.), Lesson Study: Challenges in Mathematics Education (pp.123-140). Singapore: World Scientific. https://doi.org/10.1142/9789812835420_0008

Takahashi, A. (2006). Types of elementary mathematics Lesson Study in Japan: Analysis of features and characteristics. Journal of Japan Society of Mathematical Education, Mathematics Education (in Japanese), $88(8), 2-14$.

Wei, R. C., Darling-Hammond, L., Andree, A., Richardson, N., \& Orphanos, S. (2009). Professional learning in the learning profession: A status report on teacher development in the United States and abroad. Dallas, TX: National Staff Development Council.

Yeap, B. H., Foo, P., \& Soh, P. S. (2015). Enhancing mathematics teachers' professional development through Lesson Study: A case study in Singapore. In M. Inprasitha, M. Isoda, P. Wang-Iverson, \& B. H. Yeap (Eds.), Lesson Study: Challenges in Mathematics Education (pp.153-165). Singapore: World Scientific. https://doi.org/10.1142/9789812835420_0010 


\section{Copyrights}

Copyright for this article is retained by the author(s), with first publication rights granted to the journal.

This is an open-access article distributed under the terms and conditions of the Creative Commons Attribution license (http://creativecommons.org/licenses/by/4.0/). 